\title{
Antimicrobial stewardship in residential aged care facilities: A Systematic Review
}

\author{
Ali Akhtar ${ }^{1}$, Amer Hayat Khan ${ }^{1,}{ }^{*}$, Samreen Fatima ${ }^{2}$, Mohamad Azmi Hassali ${ }^{1}$
}

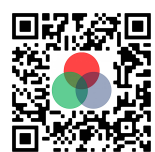

Use your smartphone to scan this QR code and download this article

${ }^{1}$ School of Pharmaceutical Sciences, Universiti Sains Malaysia, 11800 Penang, Malaysia

${ }^{2}$ University College of Pharmacy, University of the Punjab, Lahore, Pakistan

Correspondence

Amer Hayat Khan, School of Pharmaceutical Sciences, Universiti Sains Malaysia, 11800 Penang, Malaysia

Email: dramer2006@gmail.com

History

- Received: Sept 292019

- Accepted: Nov 202019

- Published: Jan 282020

DOI : 10.15419/bmrat.v7il.582

\section{Check for updates}

\section{Copyright}

(c) Biomedpress. This is an openaccess article distributed under the terms of the Creative Commons Attribution 4.0 International license.

The Open Access Publisher

\begin{abstract}
Background: Antimicrobial Stewardship (AMS) programs are increasingly implemented in healthcare facilities to reduce inappropriate use of antibiotics. Inappropriate use of antimicrobials is one of the leading causes of increasing antimicrobial resistance (AMR). As such, decreasing inappropriate use of antimicrobials can reduce AMR. The main objective of this systematic review was to identify the effectiveness of AMS interventions in reducing inappropriate antimicrobial use in residential aged care facilities (RACFs). Methods: Multiple databases were searched to identify studies evaluating the effectiveness of AMS interventions in RACFs. Descriptive studies and those, which did not report an outcome measure related to antibiotic usage, were excluded. Results: Overall, 6505 studies were identified and 17 were included. Most of the studies were randomized controlled trials and single faceted interventions. All of the interventions were education and training targeted at physicians, nurses or both about appropriate use of antimicrobials in RACFs. The studies reported a high success rate with $68 \%$ of interventions being successful while $32 \%$ of interventions were found to be ineffective. Conclusion: Educating and training nurses and physicians about evidence-based management of infectious diseases may lead to a reduction in inappropriate antimicrobial use in RACFs. The likelihood of success increases with targeting physicians - either as the sole recipient of the intervention or together- with nurses.
\end{abstract}

Key words: Antimicrobials, Interventions, Residential aged care facilities, Stewardship

\section{INTRODUCTION}

The World Health Organization (WHO) declared antimicrobial resistance (AMR) as one of the threats to human health with an estimated mortality amounting to 10 million deaths annually by $2050^{1,2}$. The causes of AMR are multifactorial. Inappropriate use of antimicrobials is one of the modifiable factors responsible for increasing AMR. The correlation between AMR and inappropriate antimicrobial use has been reported by numerous studies ${ }^{3-6}$. Moreover, more than half of the antimicrobials used in residential aged care facilities (RACFs) were inappropriate, according to different international studies ${ }^{7-10}$. Worldwide, it is estimated that 700,000 deaths every year are due to $\mathrm{AMR}^{11}$. Decreasing inappropriate use of antimicrobials can reduce AMR.

A number of factors are responsible for the significant increase in AMR including a lack of commercial production of new antimicrobials, wide use of antimicrobials in agriculture, and inappropriate or over usage of antimicrobials ${ }^{11}$. Approximately, 1.5 billion euros are spent annually in Europe ${ }^{12}$ and $\$ 200$ million in Canada due to $\mathrm{AMR}^{13}$. The government of the United Kingdom published a 5-year Antimicrobial Resistance Strategy (2013-2018) to overcome the burden of $\mathrm{AMR}^{14}$.

Due to high usage of antibiotics, antimicrobialresistant organisms are highly prevalent in RACFs $^{15,16}$. There are about 1.4 million people living in RACFs in the United States of America (USA) ${ }^{17}, 2$ million in Canada, and 1.24 million in the $\mathrm{UK}^{18}$. Approximately, 1.6 to 3 million cases of infections were diagnosed every year in the US nursing homes ${ }^{19}$. Many infections become difficult to diagnose and treat, which is a major cause of mortality and morbidity in nursing homes. This difficulty is mainly due to development of resistance or changes in the causative agents of infections ${ }^{20}$. The most common infections in RACFs are lower respiratory tract infections (LRTIs), urinary tract infections (UTIs), skin and soft tissues infections (SSTIs), and gastroenteritis (GE) ${ }^{19}$. There is a $40-70 \%$ chance of exposure to at least one course of antibiotics if a resident resides in RACFs for 6 months 21,22 .

Some studies reported that about half of the antibiotics used in RACFs are potentially inappropriate or unnecessary $^{22-27}$. The inappropriateness is mainly linked with the adequacy of empiric antibiotic choice, wrong dose, and prolonged duration of antibiotic 
use $^{28,29}$. In the EU countries, it is estimated that $57 \%$ of antibiotics are used in upper respiratory tract infections, followed by $30 \%$ in lower respiratory tract infections and $7 \%$ in urinary tract infections ${ }^{30}$. In many RACFs, the decision on prescribing antibiotics is made off-site by telephone, depending on limited laboratory and clinical information, and therefore, highly influenced by staff members of these facilities $^{31-33}$. Pressure from nursing home staff and family members leads to unnecessary prescribing of antibiotics in the American, Canadian and Australian RACFs $^{31-34}$. Responding to the widespread over-use and inappropriate use of antimicrobials, several countries have introduced quality initiatives in a bid to reduce $\mathrm{AMR}^{35,36}$.

Antimicrobial Stewardship (AMS) is a collective term used to make strategies to reduce the inappropriateness of antimicrobial use and minimize the adverse effects of the antimicrobials, which include toxicity, cost, and resistance ${ }^{37}$. AMS programs have been recommended all over the world for the better prevention and management of infections in RACFs ${ }^{38}$. A range of interventions has been developed to improve antibiotic use in RACFs; however, there is a limited understanding of the outcomes of those interventions. There is uncertainty among healthcare providers concerning optimal approaches to improve antibiotic use in $\mathrm{RACFs}^{39}$. To the best of our knowledge, there is no systematic review investigating AMS interventions in RACFs. The aim of this systemic review was to systematically identify and evaluate the effectiveness of AMS interventions in RACFs.

\section{METHODS}

\section{Search strategy and data source}

We searched CINAHL, Pubmed, Cochrane and Embase databases from inception through February 2018. A combination of Medical Subject Heading (MeSH) terms and keywords like "home for the aged", "nursing home", "residential care", "long-term care" and "infections" were used as search terms. Search details are provided in the appendix. To identify any additional relevant publications, a cross-reference search from included studies was also conducted.

The guidelines of Preferred Reporting Items for Systematic Reviews and Meta-analyses (PRISMA) Figure 2 were followed for this systematic review ${ }^{40}$. The PRISMA checklist is attached in the appendix.

\section{Selection of studies}

Titles and abstracts were screened for the identification of relevant studies. Interventions related to infections in RACFs were included in this review. Potential articles were assessed independently for inclusion (AA and SF) and any disagreement was resolved by discussion with a third reviewer (AHK).

Studies published in English in peer-reviewed journals investigating infection-related interventions conducted in RACFs were included (Figure 1).

\section{Data extraction and analysis}

One reviewer (AA) extracted relevant data from included studies with the help of Endnote software, and this was verified by a second reviewer (SF). All the extracted information was saved in the Endnote library. Extracted information from the selected studies included author, publication year, study design and setting, country of origin, type of interventions, and the outcomes and findings based on the interventions (Table 1). 


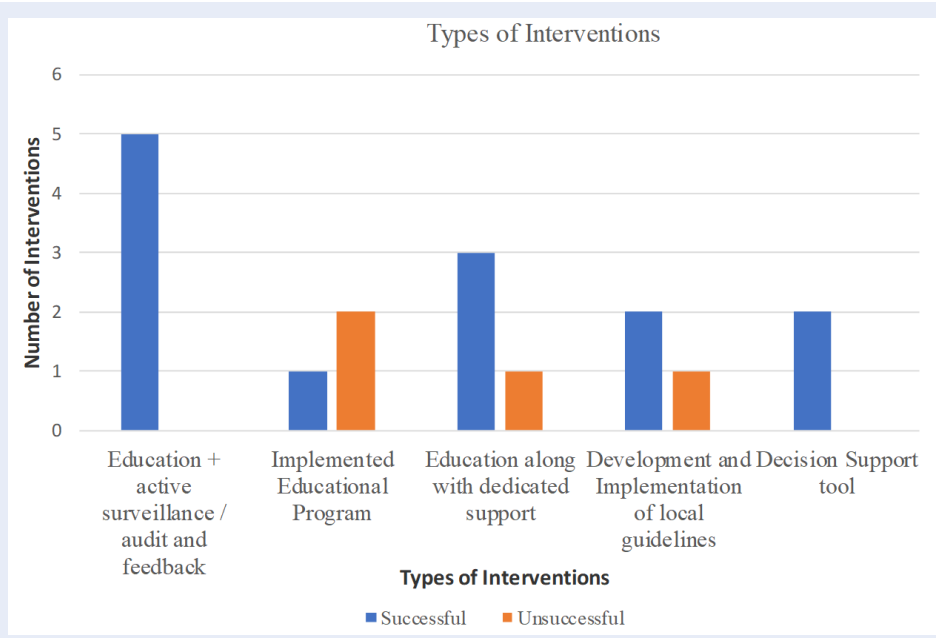

Figure 1: Types of Interventions.

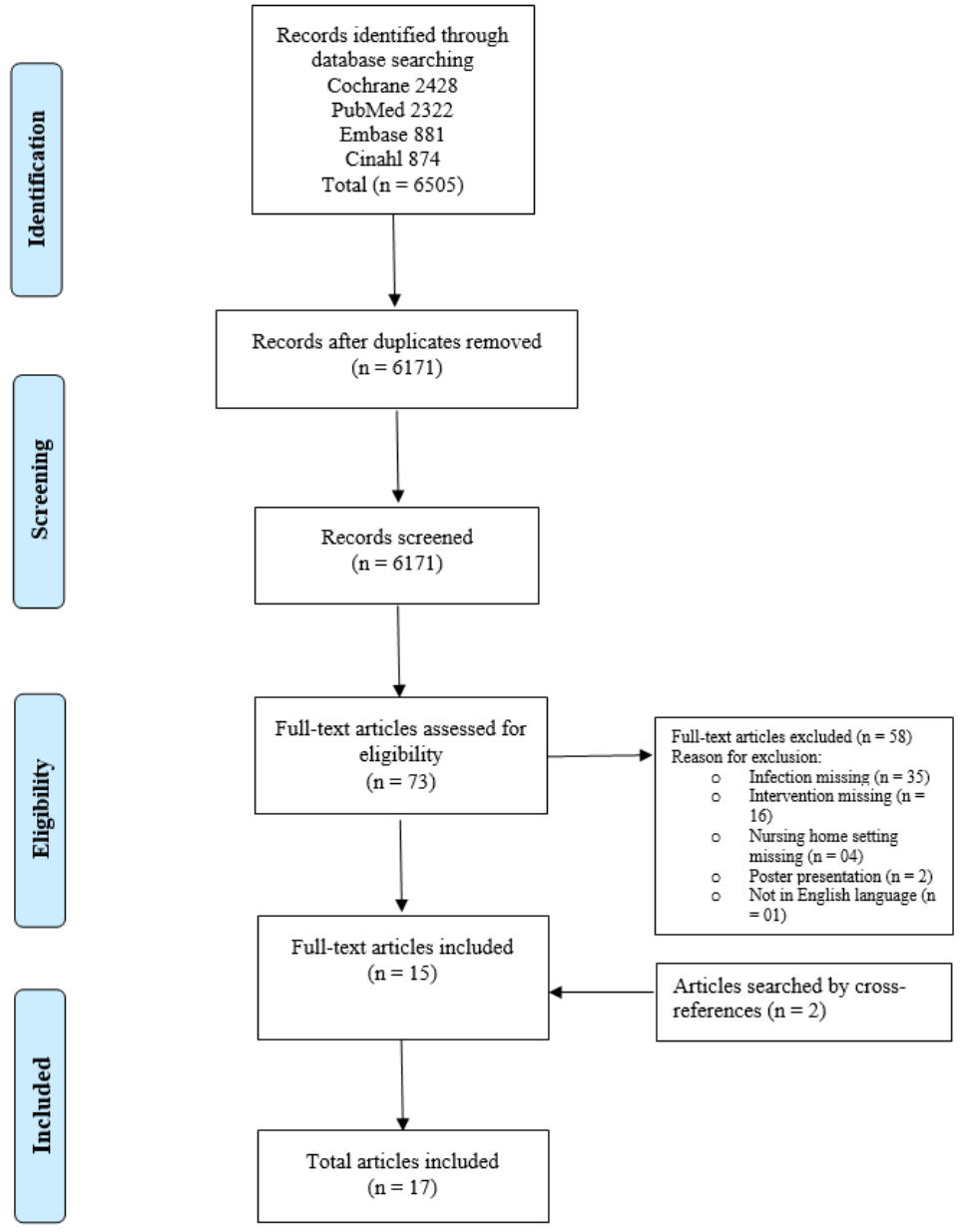

Figure 2: PRISMA Flow Diagram. 
Table 1: List of Included Studies in the Systematic Review

\begin{tabular}{|c|c|c|c|c|}
\hline Reference, year, country & Study Design & Interventions & Outcomes & Findings \\
\hline \multicolumn{5}{|c|}{ Education + active surveillance/ audit and feed back } \\
\hline Mody et al., $2015^{41}$ USA & $\begin{array}{l}\text { Randomized clinical } \\
\text { trial, } 12 \text { community- } \\
\text { based NHs }\end{array}$ & $\begin{array}{l}\text { NH staff education and active } \\
\text { surveillance of resistant infec- } \\
\text { tions (MDRO). }\end{array}$ & $\begin{array}{l}\text { Prevalence of MDRO and } \\
\text { MRSA }\end{array}$ & $\begin{array}{l}\text { Significant reduction in prevalence of } \mathrm{MDRO} \\
{[(23 \%)(\text { rate ratio, } 0.77 ; 95 \% \mathrm{CI}, 0.62-0.94 ; \mathrm{p}=0.01)]} \\
\text { and MRSA }[(22 \%) \text { rate ratio, } 0.78 ; 95 \% \mathrm{CI}, 0.64- \\
0.96 ; \mathrm{p}=0.01]\end{array}$ \\
\hline $\begin{array}{l}\text { Zimmerman et al. }{ }^{42}, 2014 \\
\text { USA }\end{array}$ & $\begin{array}{l}\text { Quasi-experimental } \\
\text { trial, } 12 \mathrm{NHs}\end{array}$ & $\begin{array}{l}\text { Educational sessions for physi- } \\
\text { cians, nurses and families of } \\
\text { residents along with feedback. }\end{array}$ & $\begin{array}{l}\text { Antibiotic prescribing rates } \\
\text { for different infections. }\end{array}$ & $\begin{array}{l}\text { Antibiotic prescription decrease by } 11.1 \text { prescrip- } \\
\text { tion per } 1000 \text { residents-days and } 1.8 \text { prescriptions } \\
\text { avoided per } 1000 \text { resident-days. }\end{array}$ \\
\hline $\begin{array}{l}\text { Pettersson et al. }{ }^{43}, 2011 \\
\text { Sweden }\end{array}$ & $\begin{array}{l}\text { Cluster randomized } \\
\text { controlled trial, } 58 \mathrm{NHs}\end{array}$ & $\begin{array}{l}\text { Education on antibiotic pre- } \\
\text { scribing with educational ma- } \\
\text { terials, audit and feedback. }\end{array}$ & $\begin{array}{l}\text { Prescription of quinolones for } \\
\text { lower UTIs in women. }\end{array}$ & $\begin{array}{l}\text { Significant decrease in quinolones prescription in } \\
\text { IG }-0.196(95 \% \mathrm{CI},-0.338,-0.054) \text { and CG }-0.224 \\
(95 \% \text { CI }-0.394,-0.054) \text {. }\end{array}$ \\
\hline Baldwin et al. ${ }^{44}, 2010 \mathrm{UK}$ & $\begin{array}{l}\text { Cluster randomised } \\
\text { controlled trial, } 32 \mathrm{NHs}\end{array}$ & $\begin{array}{l}\text { Infection control training, } \\
\text { demonstration on hand } \\
\text { hygiene, audit and feedback. }\end{array}$ & $\begin{array}{l}\text { Prevalence of MRSA among } \\
\text { residents and staff, along with } \\
\text { audit. }\end{array}$ & $\begin{array}{l}\text { Prevalence of MRSA was non-significant however, } \\
\text { mean infection audit score was increased }(82 \%)(p \\
<0.0001) \text { at } 12 \text { months. }\end{array}$ \\
\hline $\begin{array}{l}\text { Monette et } a l .{ }^{45}, 2007 \\
\text { Canada }\end{array}$ & $\begin{array}{l}\text { Cluster randomized, } \\
\text { controlled trial, } 8 \text { LTC } \\
\text { facilities }\end{array}$ & $\begin{array}{l}\text { Mailing of antibiotic guide } \\
\text { along with previous } 3 \text { months } \\
\text { antibiotic prescribing pattern } \\
\text { to } 36 \text { physicians twice with } 4 \\
\text { months difference. }\end{array}$ & $\begin{array}{l}\text { Adherence to antibiotic pre- } \\
\text { scribing guidelines. }\end{array}$ & $\begin{array}{l}\text { Physicians were } 64 \% \text { less likely to prescribe non- } \\
\text { adherent antibiotics in IG }(\mathrm{OR}=0.36,95 \% \mathrm{CI}, 0.18 \text { - } \\
0.73) \text {. }\end{array}$ \\
\hline \multicolumn{5}{|c|}{ Implemented Educational program } \\
\hline $\begin{array}{l}\text { Van Gaal et al. }{ }^{46}, 2010 \\
\text { Netherlands }\end{array}$ & $\begin{array}{l}\text { Cluster randomised } \\
\text { trial, } 10 \text { Hospital wards } \\
\text { and } 10 \text { nursing home } \\
\text { wards }\end{array}$ & $\begin{array}{l}\text { The educational material con- } \\
\text { sisted of an educational com- } \\
\text { pact disc for nurses. }\end{array}$ & $\begin{array}{l}\text { The test score of nurses for } \\
\text { pressure ulcers and UTIs. }\end{array}$ & $\begin{array}{l}\text { Non-significant UTIs knowledge was observed } \\
[0.17 \text { points ( } 95 \% \text { CI; }-0.31 \text { to } 0.65)] \text { however; } \\
\text { knowledge on pressure ulcers was statistically sig- } \\
\text { nificant }[0.45 \text { points ( } 95 \% \text { CI; } 0.10-0.81)] \text {. }\end{array}$ \\
\hline $\begin{array}{l}\text { Zabarsky et al. }{ }^{47}, \\
2008 \text { USA }\end{array}$ & $\begin{array}{l}\text { Before/ After, Single } \\
\text { LTCF }\end{array}$ & $\begin{array}{l}\text { Education to physicians about } \\
\text { diagnosis and treatment of } \\
\text { ASB and nurses about the } \\
\text { urine cultures for UTIs. }\end{array}$ & $\begin{array}{l}\text { Treatment of ASB and appro- } \\
\text { priateness of urine cultures. }\end{array}$ & $\begin{array}{l}\text { Inappropriate treatment reduces from } 1.7 \text { to } 0.6 \text { per } \\
1000 \text { patient days }(\mathrm{p}=0.0017) \text { and urine cultures } \\
\text { decreased from } 2.6 \text { to } 0.9 / 1000 \text { patient days ( }<< \\
0.0001 \text { ). }\end{array}$ \\
\hline
\end{tabular}

Continued on next page 


\begin{tabular}{|c|c|c|c|c|}
\hline \multicolumn{5}{|c|}{ Table 1 continued } \\
\hline Reference, year, country & Study Design & Interventions & Outcomes & Findings \\
\hline $\begin{array}{l}\text { Hasson et al. }{ }^{48}, 2006 \text { Swe- } \\
\text { den }\end{array}$ & $\begin{array}{l}\text { Prospective, } \quad \text { non- } \\
\text { randomized, controlled } \\
\text { intervention, } 2 \text { elderly } \\
\text { care organizations }\end{array}$ & $\begin{array}{l}16 \text { item educational tool for } \\
\mathrm{NH} \text { staff and residents families } \\
\text { for management of infections. }\end{array}$ & $\begin{array}{l}\text { The effect of the educational } \\
\text { intervention on NH staff, resi- } \\
\text { dents and their families to im- } \\
\text { prove the quality of care. }\end{array}$ & $\begin{array}{l}\text { There were no significant changes in quality of care } \\
\text { as perceived by residents or their families. }\end{array}$ \\
\hline \multicolumn{5}{|c|}{ Education along with dedicated support } \\
\hline $\begin{array}{l}\text { Van Buul et al. }{ }^{49}, 2015 \\
\text { Netherlands }\end{array}$ & $\begin{array}{l}\text { Quasi-experimental, be- } \\
\text { fore/after, } 10 \mathrm{NHs}\end{array}$ & $\begin{array}{l}\text { Improve physician knowledge, } \\
\text { physician-nursing staff com- } \\
\text { munication, Optimizing med- } \\
\text { ication formularies and utiliza- } \\
\text { tion of diagnostic resources. }\end{array}$ & $\begin{array}{l}\text { Appropriate decisions regard- } \\
\text { ing prescribing or withhold- } \\
\text { ing antibiotics for every infec- } \\
\text { tion. }\end{array}$ & $\begin{array}{l}\text { No pre- post- test difference in appropriate pre- } \\
\text { scribing decisions in the intervention group }(82 \% \\
\text { to } 79 \% ; \mathrm{p}=0.28)\end{array}$ \\
\hline $\begin{array}{l}\text { Jump et al. }{ }^{50} \text {, } \\
2012 \text { USA }\end{array}$ & Before/After, 4 LTCFs & $\begin{array}{l}\text { LID consult team along with } 24 \\
\text { hours telephone support. }\end{array}$ & $\begin{array}{l}\text { Total use of antimicrobials in } \\
\text { LTCFs. }\end{array}$ & $\begin{array}{l}\text { Reduction in the use of antimicrobials by } 30.1 \% \text { ( } p \\
<0.001 \text { ). }\end{array}$ \\
\hline Daly et al. ${ }^{51}, 1992$ USA & Before/After, $3 \mathrm{NHs}$ & $\begin{array}{l}\text { Two days infection control } \\
\text { training along with telephone } \\
\text { support. }\end{array}$ & $\begin{array}{l}\text { To evaluate the knowledge } \\
\text { and practices of } \mathrm{NH} \text { staff re- } \\
\text { garding management of infec- } \\
\text { tions. }\end{array}$ & $\begin{array}{l}\text { Knowledge: after training overall a } 25 \% \text { increase in } \\
\text { correctly answered questions }(\mathrm{F}=1024 ; \mathrm{df}=1 / 263 ; \\
\mathrm{p}<0.0001) \text {. } \\
\text { Significant time spent on infection control }(\mathrm{F}=37 \\
\mathrm{df}=1 / 209 ; \mathrm{p}<0.0001) \text { after training than before } \\
\text { training. } \\
\text { Significant increase in practices for all training sites } \\
(\mathrm{F}=139.5 ; \mathrm{df}=1 / 209, \mathrm{p}<0.0001) .\end{array}$ \\
\hline $\begin{array}{l}\text { Linnebur et al. }{ }^{52}, 2011 \\
\text { USA }\end{array}$ & $\begin{array}{l}\text { Quasi-experimental } \\
\text { study, } 16 \mathrm{NHs}\end{array}$ & $\begin{array}{l}\text { Academic detailing to physi- } \\
\text { cians by pharmacists and ed- } \\
\text { ucational sessions for nurses } \\
\text { regarding diagnostic and pre- } \\
\text { scribing practices of NHAP. }\end{array}$ & $\begin{array}{l}\text { Adherence to antibiotic } \\
\text { guidelines. }\end{array}$ & $\begin{array}{l}\text { Antibiotic guidelines adherence increases from } \\
60 \% \text { to } 66 \%(p=0.3) \text {. }\end{array}$ \\
\hline \multicolumn{5}{|c|}{ Development and Implementation of local guidelines } \\
\hline
\end{tabular}




\begin{tabular}{|c|c|c|c|c|}
\hline \multicolumn{5}{|c|}{ Table 1 continued } \\
\hline Reference, year, country & Study Design & Interventions & Outcomes & Findings \\
\hline $\begin{array}{l}\text { Rummukainen et al. }{ }^{53} \text {, } \\
2012 \text { Finland }\end{array}$ & $\begin{array}{l}\text { Before/After } \\
39 \mathrm{NH}\end{array}$ & $\begin{array}{l}\text { Development of guidelines for } \\
\text { diagnostic practices for UTIs } \\
\text { and educating NH staff about } \\
\text { them. }\end{array}$ & $\begin{array}{l}\text { Antibiotic prophylaxis used } \\
\text { for UTIs. }\end{array}$ & $\begin{array}{l}\text { Decreased the use of antibiotics for UTIs from } 13 \% \\
\text { to } 6 \% \text {. }\end{array}$ \\
\hline Schwartz et al. ${ }^{54}, 2007$ USA & $\begin{array}{l}\text { Quasi-experimental } \\
\text { before-after }\end{array}$ & $\begin{array}{l}\text { Teaching sessions for physi- } \\
\text { cians about guidelines for } \\
\text { management of infections. }\end{array}$ & $\begin{array}{l}\text { Management of infections } \\
\text { along with treatment based } \\
\text { on the guidelines. }\end{array}$ & $\begin{array}{l}\text { Charted clinical abnormalities met guideline diag- } \\
\text { nostic criteria: } 62 \% \text { vs } 38 \%(p=0.006) \text { and treat- } \\
\text { ment based on guidelines: } 39 \% \text { vs } 11 \%(p<0.001) \text {. }\end{array}$ \\
\hline $\begin{array}{l}\text { Naughton et al. }{ }^{55}, 2001 \\
\text { USA }\end{array}$ & $\begin{array}{l}\text { Randomized controlled } \\
\text { trial, } 10 \text { Skilled nursing } \\
\text { facilities }\end{array}$ & $\begin{array}{l}\text { NHAP guidelines develop- } \\
\text { ment and educating physicians } \\
\text { and nurses (pocket booklets). }\end{array}$ & Antibiotic adherence. & $\begin{array}{l}\text { No significant difference was found between pre } \\
\text { and post intervention groups }(\mathrm{p}=0.86) \text {. }\end{array}$ \\
\hline \multicolumn{5}{|l|}{ Decision Support Tools } \\
\hline Fleet et al. ${ }^{56}, 2014 \mathrm{UK}$ & $\begin{array}{l}\text { Cluster randomized } \\
\text { control, } 30 \mathrm{NHs}\end{array}$ & $\begin{array}{l}\text { Introduction of Resident } \\
\text { Antimicrobial Management } \\
\text { Plan (RAMP) antimicrobial } \\
\text { stewardship tool completed by } \\
\text { nursing staff for all residents. }\end{array}$ & $\begin{array}{l}\text { Change in use of systemic an- } \\
\text { tibiotics for the treatment of } \\
\text { infections. }\end{array}$ & $\begin{array}{l}\text { Significantly decreased in prescription rate by } 4.9 \% \\
(95 \% \text { CI } 1.0 \% \text { to } 8.6 \% ; \mathrm{p}=0.02) \text {. }\end{array}$ \\
\hline $\begin{array}{l}\text { Loeb et al. }{ }^{57}, 2005 \text { Canada } \\
\text { and USA }\end{array}$ & $\begin{array}{l}\text { Cluster randomised } \\
\text { controlled trial, } 24 \mathrm{NHs}\end{array}$ & $\begin{array}{l}\text { Specific algorithms for physi- } \\
\text { cians and nurses regarding } \\
\text { UTIs, individual interviews } \\
\text { with physicians. }\end{array}$ & $\begin{array}{l}\text { Antimicrobials prescribed for } \\
\text { suspected UTIs, antimicro- } \\
\text { bials leading to hospital ad- } \\
\text { missions or death. }\end{array}$ & $\begin{array}{l}\text { 1.The rate of antimicrobial use for suspected uri- } \\
\text { nary tract infection was significantly lower in the } \\
\text { intervention arm than in usual care arm ( } 1.17 \\
\text { courses of antimicrobials per } 1000 \text { resident days } \\
\text { prescribed vs } 1.59 \text {; weighted mean difference }-0.49 \text {, } \\
95 \% \text { CI }-0.93 \text { to }-0.06 \text { ). } \\
\text { 2. No significant difference was found in admis- } \\
\text { sions to hospital or mortality between the study } \\
\text { arms. }\end{array}$ \\
\hline
\end{tabular}

NH: nursing home, UTI: urinary tract infection, LTCFs: Long-term carefacilities, NHAP: nursing home acquired pneumonia, MRSA: methicillin-resistant Staphylococcus aureus, MDRO: multi-drugresistant organisms, NHAP: nursing home acquired pneumonia, LID: Long-term care facilities Infectious Disease. 


\section{Quality assessment}

Two reviewers (AA and SF) independently carried out the quality assessment of included studies by using the Effective Public Health Practice Project (EPHPP) Quality Assessment Tool ${ }^{58}$ (Appendix). This tool evaluates six quality-related domains like study design, selection bias, blinding, confounders, withdrawals and dropouts, and data collection methods. Any disagreement was resolved by discussion with a third reviewer (AHK).

\section{RESULTS}

\section{Description of included studies}

Seventeen articles met the inclusion criteria (Figure 1). Table 1 summarizes the study characteristics. Most studies were conducted in North America with 8 in the USA ${ }^{42,45,47,50-52}, 1$ in Canada ${ }^{57}$, and 1 as a multicenter study in the USA and Canada ${ }^{44}$. The remaining 7 studies were conducted in Europe with 2 in the United Kingdom ${ }^{46,56}, 2$ each in the Netherlands ${ }^{43,48}$ and Sweden ${ }^{49,53}$, and 1 in Finland ${ }^{58}$.

Most of the studies $(\mathrm{n}=10)$ were randomized controlled trials (RCTs) and 7 studies were quasiexperimental trials. Two out of 10 RCTs were standard RCTs while 8 were cluster RCTs (c-RCTs). Most quasi-experimental trails $(n=7)$ were before-and-after study design. The number of included RACFs varied greatly from 2 RACFs to 58 RACFs (Table 1).

\section{Types of interventions}

Most studies used educational interventions (70.6\%, $\mathrm{n}=12$ ), of which 4 studies used an educational component along with a support (through dedicated personnel), 5 studies used an educational component in addition to an active surveillance of resistant infections and/or audit and feedback, while 3 studies implemented an education only program. The remaining studies employed interventions related to the development and implementation of local guidelines $(17.7 \%, \mathrm{n}=3)$ and the use of decision support tools $(11.7 \%, \mathrm{n}=2)$ (Table 1$)$.

\section{Educational interventions}

Three studies ${ }^{43,50,53}$ that implemented education only interventions introduced an educational compact disc $(C D)^{43}$, a 16 -item instrument ${ }^{53}$ for nursing staff to improve the knowledge regarding infections, and an educational support to physicians and nurses about the diagnosis and treatment of asymptomatic bacteriuria (ASB) and the urine cultures for UTIs, respectively. The first two interventions did not provide a statistically significant increase in knowledge of nursing staff, but the third intervention reduced inappropriate treatment of ASB from 167.1 to $117.4 / 1000$ patient days $(\mathrm{p}<0.001)$ and the number of urine cultures decreased from 2.6 to $0.9 / 1000$ patient days $(\mathrm{p}<0.0001)$.

Four studies included educational interventions along with dedicated personnel support ${ }^{48,51,52,54}$. One of the interventions was to improve the communication of the physicians and nurses through discussion meetings regarding the management of infections in $\mathrm{RACFs}^{48}$. Medication formularies were optimized along with correct utilization of diagnostic tools to support decisions whether or not to prescribe or withhold antibiotics for any infection. There was no prepost test difference in appropriate prescribing decisions in the intervention group (IG) (82\% to $79 \%$; $\mathrm{p}=0.28)$. Moreover, appropriateness in the control group (CG) was also not increased (70\% to $77 \%$; $p$ $=0.06$ ). One study investigated the effect of twoday infection control training on nursing staff to evaluate their knowledge and practices about the management of infections in RACFs ${ }^{52}$. This intervention increased the knowledge of nursing staff by $25 \%$ $(\mathrm{F}=1024 ; \mathrm{df}=1 / 263 ; \mathrm{p}<0.0001)$ and significantly improved nurses' practices regarding the treatment of infections ( $F=139.5 ; \mathrm{df}=1 / 209, \mathrm{p}<0.0001)$. In a study investigating the effects of an infectious disease control team with $24 \mathrm{hr}$ telephone support to improve the appropriate use of antimicrobials, post-intervention inappropriate use was reduced by $30.1 \%(\mathrm{p}<0.001)^{51}$. In another study, pharmacists gave academic detailing to physicians and provided educational sessions to nurses to improve their adherence to nursing homeacquired pneumonia (NHAP) guidelines ${ }^{54}$. Adherence score for optimal antibiotic use increased from $60 \%$ to $66 \%$ but it was not statistically significant ( $\mathrm{p}=$ 0.3 ) and adherence to guidelines regarding the use of antibiotics within the first 4 hours of NHAP diagnosis increased from $57 \%$ to $75 \%(\mathrm{p}<0.001)$.

Five studies involved educational interventions along with active surveillance and audit/feedback for better management of infections in RACFs. In one study, mailing of an antibiotic guide with the past 3-month prescribing patterns improved the use of antibiotics. Post-intervention findings revealed that physicians were $64 \%$ less likely to prescribe non-adherent antibiotics in the IG $(\mathrm{OR}=0.36,95 \% \mathrm{CI}, 0.18-0.73)^{57}$. In another study, educational materials including leaflets and handouts for physicians, followed by audit and feedback, resulted in a significant decrease in quinolone prescription in IG -0.196 (95\% CI, -0.338, $0.054)$ and CG $-0.224(95 \% \text { CI }-0.394,-0.054)^{49}$. Two 
studies investigated the effect of education on nursing staff about infections caused by multi-drug resistant organisms (MDRO) and methicillin-resistant Staphylococcus aureus (MRSA) ${ }^{42,56}$. One study ${ }^{42}$ conducted active surveillance for MDRO related infections while other another study ${ }^{56}$ conducted infection control audits. MDRO prevalence decreased by $23 \%$ in the IG (rate ratio RR $0.77 ; 95 \% \mathrm{CI}, 0.62$ $0.94)^{42}$, while there was no significant difference in MRSA infections ${ }^{56}$. The final intervention included educational training for physicians and nurses regarding antibiotic-prescribing guidelines. Feedback on antibiotic prescribing was also shared with the healthcare professionals. This intervention helped to reduce prescriptions for antibiotics in RACFs [IRR 0.86 (95\% CI 0.79 - 0.90)].

\section{Development and implementation of local guidelines}

Three out of 17 studies developed and implemented guidelines for the prevention and management of infections in RACFs ${ }^{45,58,59}$. Two studies developed and implemented guidelines to improve antimicrobial prescribing in nursing homes for infectious diseases, including NHAP and UTIs ${ }^{45,58}$. Adherence to NHAP guidelines increased significantly in the post-intervention group $(\mathrm{p}<0.02)^{45}$, while the use of antibiotics decreased from $13 \%$ to $6 \%(\mathrm{p}<0.001)$ in the case of UTIs ${ }^{58}$. In one study, teaching sessions were conducted for physicians on the guidelines for the management of infections. These sessions met guideline diagnostic criteria: $62 \%$ vs $38 \%$ ( $p=0.006)$, and treatment based on guidelines: $39 \%$ vs $11 \%(p<0.001)^{59}$.

\section{Decision support tools}

One study introduced a Resident Antimicrobial Management Plan (RAMP) to improve the use of antibiotics in nursing homes. The purpose of RAMP was to document the prescribing, administration, and monitoring of antimicrobials ${ }^{46}$. The RAMP decreased $4.9 \%$ (95\% CI: $1.0 \%-8.6 \%$ ) of the antibiotic prescription in the intervention group as compared to the control group. Another study introduced diagnostic and therapeutic algorithms for UTIs which resulted in a significant decrease in the use of antimicrobials in the intervention arm than in usual care arm (1.17 courses of antimicrobials per 1000 resident days prescribed vs 1.59 ; weighted mean difference $-0.49,95 \%$ CI -0.93 to $-0.06)^{44}$.

\section{Features of successful interventions}

Figure 1 shows a breakdown of interventions and their relative successfulness in improving the use of antibiotics in RACFs. Of all educational interventions ( $n=12), 9$ interventions $(64.3 \%)$ were successful in improving the antibiotic use. However, it is noteworthy to mention that educational interventions that were combined with other interactive active surveillance/audit/feedback (80\%) and personnel support (66.7\%) were more effective than education only interventions (33.3\%). Other interventions, such as development and implementation of guidelines $(n=2)$ and the use of decision support tools $(n=2)$, were all successful in improving antimicrobial use. Studies that used quasi-experimental design implemented more interventions successfully (75\%) than studies using randomized control trial (70\%).

\section{Quality Assessment}

According to the Effective Public Health Practice Project (EPHPP) quality assessment tool, most of the studies $(\mathrm{n}=13)$ were rated as moderate quality (Appendix). The reason behind this is the information lacking about the blinding of the studies ${ }^{43-46,48,51,52,56}$. The remaining four studies were rated as strong quality since the information in these studies was very clear and comprehensive ${ }^{41,42,55,57}$.

\section{DISCUSSION}

\section{Importance of this review}

Advances in healthcare mean that the relative proportion of people living in RACFs is likely to increase over the considerable foreseeable future. Emerging reports of increasing antimicrobial resistance in RACFs is a growing concern amongst the residents, healthcare professionals, and managers of RACFs. Not surprisingly, there has been an increasing interest in the development and implementation of AMS initiatives in the RACFs worldwide. Since there was a paucity of information regarding the successful interventions to improve antimicrobial use in RACFs, this systematic review was conducted to provide an overview of different infection-related interventions in RACFs all over the world.

\section{Principal findings}

This systematic review found seventeen studies that assessed the interventions to improve antimicrobial 
use in RACFs. The educational interventions combined with other strategies and the multifaceted interventions mostly showed consistent and positive effects in improving the use of antimicrobial in RACFs.

\section{Comparison with existing literature}

In the current systematic review, educational strategies were the most frequently used intervention to improve the use of antimicrobials in RACFs. Similar findings were reported by another review that evaluated quality interventions in the outpatient setting ${ }^{60}$. However, the referenced study reported some form of clinicians' education $(\mathrm{n}=27)$ and patients' education $(n=18)$, while most studies in the current review mainly focussed on healthcare professionals' education. The importance of multidisciplinary interventions targeting different stakeholders of the health system, including patients, has been emphasised elsewhere ${ }^{54}$. The findings of this review show that educational interventions supplemented with other strategies were more successful compared with education only interventions. Previous reviews have also highlighted the limited impact of education only strategies in ambulatory settings ${ }^{61,62}$. This finding can be best explained by the multifactorial nature of inappropriate antibiotic prescribing that demands the implementation of multi-intervention addressing the root cause of inappropriate prescribing. Simply diverting the clinicians' attention towards their current behaviour through audits, prescribing feedback, or suggesting an alternate behaviour may not help the cause of antimicrobial stewardship ${ }^{63}$. Similarly, the positive effects of implementing guidelines and decision support tools in RACFs can be compared with studies conducted in other settings which reported the potential of these interventions in improving antimicrobial prescribing practices ${ }^{64-66}$.

\section{Educational interventions}

Given the broad array of educational interventions, it is difficult to arrive at specifically applicable educational interventions to improve antibiotic use in RACFs. Generally, educational interventions are classified as active or passive interventions, depending on their nature and the way of implementation. Passive interventions have been least successful in improving the use of antibiotics in inpatient and ambulatory settings ${ }^{63,66}$. However, there is a paucity of information about the supplementary effects of passive education along with other interventions. The use of reference cards to improve the knowledge of physicians and nurses was the only successful education-only intervention in this review. Though this intervention was more inclined towards a passive mode of providing education, it had the potential to shape or change behaviour of healthcare professionals towards antibiotic prescribing. The conventional way of providing the education to improve the knowledge of clinicians is not sufficient. However, if the education can effectively change the attitudes or behaviour of clinicians towards antimicrobial prescribing, it can certainly play a crucial role in antimicrobial stewardship. The similar concept of education can also be applied to education in hospital infection prevention, clinical performance improvement, and public health ${ }^{67}$. It was noted in this systematic review that educationwhen combined with other dynamic and interactive interventions, such as active surveillance of resistant infection, audit, and feedback- and educational training sessions resulted in significant improvement in antimicrobial use. The use of educational interventions to improve antimicrobial use in RACFs is still in its infancy stage. Overall, well-designed educational interventions have great potential to improve antimicrobial prescribing in RACFs. Future educational strategies should target the behavioral change of clinicians towards antimicrobial prescribing.

\section{Development and implementation of local guidelines}

Non-educational interventions have proven to be effective in improving antimicrobial prescribing practices. Development and implementation of guidelines were effective in decreasing antibiotic use in RACFs. However, it is important to note that two studies that supported this finding employed multifaceted interventions. Along with the implementation of guidelines, one study ${ }^{58}$ employed an interpersonal communication between a team of infectious disease experts and nursing home staff while in another study ${ }^{45}$, small group sessions were conducted with physicians and nurses about antimicrobial guidelines. Therefore, it is suggested that implementation of guidelines alone may not be effective to improve antibiotic use in a facility. Multifaceted strategies for increased dissemination, awareness, and uptake of medicines can augment the effectiveness of guidelines in strengthening antimicrobial stewardship programs.

\section{Use of decision support tools}

The use of decision support tools (RAMP and diagnostic and treatment algorithm) significantly reduced the rate of antimicrobial prescribing in RACFs. 
However, the use of RAMP was supplemented with a written educational material ${ }^{46}$. Besides, the use of diagnostic and treatment algorithm was employed through multifaceted interventions, including group discussions, printed educational material, outreach visits, and interviews. Caution should be made in generalizing the findings of Loeb et al. since the study only looked at the antimicrobial prescribing for UTIs. Further advancement could be made by incorporating computerized clinical decision support system in RACFs. The implementation of this system in hospital settings has shown significant improvement in reducing the use of broad-spectrum antibiotics ${ }^{68}$. The development of computer-based clinical decision support system could be beneficial for an antimicrobial stewardship program in RACFs.

\section{Study design and quality}

The use of randomized controlled trials in evaluating the effect of interventions in an antimicrobial stewardship program provides strong evidence because of the ability to account for confounding factors. The use of cluster randomized control trials also helps to improve the internal and external validity of the results; however, their design and statistical analysis are more complex than the standard patient-level randomized control trials. Most studies in this review used cluster randomized control trials but the success rate was lowest among all other study designs. The use of complex design might have played a role in the outcomes of interventions. The issue of clustering in determining the sample size was apparent in the reviewed studies. The methodological weakness including the blinding, allocation status, and adherence to guidelines on methodological quality was also observed in the reviewed studies. It is also important to discuss cross-contamination that may have occurred between intervention and control group. It can happen if the participants in both groups have close personal or professional relationship, in which intervention can be shared with the control group which may give false negative results. It is important to investigate whether or not the use of complex interventions using c-RCTs is more, less, or equally effective than standard RCTs in RACFs.

Quasi-experimental design is often used to evaluate the effects of population-level interventions, but the strength of this design varies according to design features. Therefore, it is suggested that a higherorder design should be used when conducting quasiexperiments. Interrupted time series (ITS) is considered as the most robust design for causal inference.
Only one study in this review used ITS in combination with before-and-after study design. Though the implementation of successful interventions was higher in studies using QE designs, studies with stronger methodological quality are required to increase the strength of scientific evidence.

\section{Strengths and limitations}

This review provides a great insight into the published literature that evaluated the effects of interventions to improve antimicrobial use in RACFs. The review draws attention to issues which have implications for practice and research. Concurrently, the findings of this study should be viewed considering some limitations. Most studies in this review were of a moderate quality which may limit the applicability of findings in the clinical setting. Given a relatively small number of studies and a significant variation in interventions, caution should be made while interpreting the results. About half of the studies used quasi-experimental and uncontrolled before/after design that are at high risk of bias. Hence, the successful interventions using these designs should be interpreted with caution. Grey literature, unpublished studies, and articles written in languages other than English were not included in this study. Despite a comprehensive review process for study selection, the possibility to exclude relevant articles inadvertently remains.

\section{CONCLUSION}

This review shows that educational interventions are most effective when combined with other interactive interventions. The majority of educational interventions are aimed at improving the knowledge the health professionals about antibiotic use. Multifaceted interventions targeting the prescribing behaviour may successfully improve antimicrobial stewardship in RACFs. Future studies should use more robust study design to enhance the quality of evidence. More research is needed to design, implement and evaluate innovative educational and non-educational stewardship interventions, and to investigate the facilitators and barriers to implementation.

\section{ABBREVIATIONS}

AMS: Antimicrobial Stewardship

AMR: Antimicrobial Resistance

RACFs: Residential Aged Care Facilities

WHO: World Health Organization

LRTIs: Lower Respiratory Tract Infections

UTIs: Urinary Tract Infections

SSTIs: Skin and Soft Tissue Infections 
MeSH: Medical Subject Heading

PRISMA: Preferred Reporting Items for Systematic Reviews and Meta-analyses

EPHPP: Effective Public Health Practice Project

ITS: Interrupted Time Series

\section{COMPETING INTERESTS}

The author(s) declare that they have no competing interests.

\section{AUTHORS' CONTRIBUTIONS}

All the authors have participated in manuscript preparation, Manuscript review, Design, Literature search, Manuscript editing. All authors read and approved the final version of manuscript.

\section{ACKNOWLEDGEMENT}

The authors are thankful to Institute of Postgraduate Studies (IPS) of Universiti Sains Malaysia (USM) for fellowship support.

\section{REFERENCES}

1. Sharma A. Antimicrobial resistance: no action today, no cure tomorrow. Indian J Med Microbiol. 2011;29(2):91-2. PMID: 21654100. Available from: 10.4103/0255-0857.81774.

2. de Kraker ME, Stewardson AJ, Harbarth S. Will 10 million people die a year due to antimicrobial resistance by 2050? PLoS Med. 2016;13(11):e1002184. PMID: 27898664. Available from: 10.1371/journal.pmed.1002184.

3. Ferech M, Coenen S, Malhotra-Kumar S, Dvorakova K, Hendrickx E, Suetens $C$, et al. European Surveillance of Antimicrobial Consumption (ESAC): outpatient antibiotic use in Europe. J Antimicrob Chemother. 2006;58(2):401-7. PMID: 16735414. Available from: 10.1093/jac/dkl188.

4. Brooks L, Shaw A, Sharp D, Hay AD. Towards a better understanding of patients' perspectives of antibiotic resistance and MRSA: a qualitative study. Fam Pract. 2008;25(5):341-8. PMID: 18647956. Available from: 10.1093/fampra/cmn037.

5. Simpson SA, Wood F, Butler CC. General practitioners' perceptions of antimicrobial resistance: a qualitative study. J Antimicrob Chemother. 2007;59(2):292-6. PMID: 17110392. Available from: $10.1093 / \mathrm{jac} / \mathrm{dkl} 467$.

6. Metlay JP, Strom BL, Asch DA. Prior antimicrobial drug exposure: a risk factor for trimethoprim-sulfamethoxazoleresistant urinary tract infections. J Antimicrob Chemother. 2003;51(4):963-70. PMID: 12654756. Available from: 10.1093/ jac/dkg146.

7. McClean P, Tunney M, Gilpin D, Parsons C, Hughes C. Antimicrobial prescribing in nursing homes in Northern Ireland: results of two point-prevalence surveys. Drugs Aging. 2011;28(10):819-29. PMID: 21970309. Available from: 10.2165/11595050-000000000-00000.

8. McGeer A, Campbell B, Emori TG, Hierholzer WJ, Jackson MM, Nicolle LE, et al. Definitions of infection for surveillance in long-term care facilities. Am J Infect Control. 1991;19(1):1-7. PMID: 1902352. Available from: 10.1016/0196-6553(91)901545.

9. Nicolle LE, Bentley DW, Garibaldi R, Neuhaus EG, Smith PW, Committee SLTC. Antimicrobial use in long-term-care facilities. Infect Control Hosp Epidemiol. 2000;21(8):537-45. PMID: 10968724. Available from: $10.1086 / 501798$.

10. Peron EP, Hirsch AA, Jury LA, Jump RL, Donskey CJ. Another setting for stewardship: high rate of unnecessary antimicrobial use in a veterans affairs long-term care facility. J Am Geri- atr Soc. 2013;61(2):289-90. PMID: 23405923. Available from: 10.1111/jgs.12099.

11. Cecchini M, Langer J, Slawomirski L. Antimicrobial Resistance in G7 Countries and Beyond: Economic Issues, Policies and Options for Action. Paris: Organization for Economic Cooperation and Development; 2015.

12. Organization $\mathbf{W H}$. The evolving threat of antimicrobial resistance: options for action. World Health Organization; 2012.

13. Conly J. Antimicrobial resistance in Canada. CMAJ. 2002;167(8):885-91. PMID: 12406948.

14. Davies S, Gibbens N. UK five year antimicrobial resistance strategy 2013 to 2018. London: Department of Health; 2013.

15. Stuart RL, Kotsanas D, Webb B, Vandergraaf S, Gillespie EE, Hogg GG, et al. Prevalence of antimicrobial-resistant organisms in residential aged care facilities. Med J Aust. 2011;195(9):530-3. PMID: 22060088. Available from: 10.5694/ mjal1.10724.

16. Chua KY, Stewardson AJ. Individual and community predictors of urinary ceftriaxone-resistant Escherichia coli isolates, Victoria, Australia. Antimicrob Resist Infect Control. 2019;8(1):36. PMID: 30805183. Available from: 10.1186/ s13756-019-0492-8.

17. Harris-Kojetin L, Sengupta M, Park-Lee E, Valverde R. LongTerm Care Services in the United States: 2013 Overview; 2013.

18. Crnich CJ, Jump R, Trautner B, Sloane PD, Mody L. Optimizing antibiotic stewardship in nursing homes: a narrative review and recommendations for improvement. Drugs Aging. 2015;32(9):699-716. PMID: 26316294. Available from: 10.1007/s40266-015-0292-7.

19. Montoya A, Cassone M, Mody L. Infections in nursing homes: epidemiology and prevention programs. Clin Geriatr Med. 2016;32(3):585-607. PMID: 27394025. Available from: 10. 1016/j.cger.2016.02.004.

20. Strausbaugh LJ. Emerging health care-associated infections in the geriatric population. Emerg Infect Dis. 2001;7(2):26871. PMID: 11294721 . Available from: 10.3201/eid0702.010224.

21. Benoit SR, Nsa W, Richards CL, Bratzler DW, Shefer AM, Steele LM, et al. Factors associated with antimicrobial use in nursing homes: a multilevel model. J Am Geriatr Soc. 2008;56(11):2039-44. PMID: 19016937. Available from: 10. 1111/j.1532-5415.2008.01967.x.

22. Warren JW, Palumbo FB, Fitterman L, Speedie SM. Incidence and characteristics of antibiotic use in aged nursing home patients. J Am Geriatr Soc. 1991;39(10):963-72. PMID: 1918783. Available from: 10.1111/j.1532-5415.1991.tb04042.x.

23. Rotjanapan P, Dosa D, Thomas KS. Potentially inappropriate treatment of urinary tract infections in two Rhode Island nursing homes. Arch Intern Med. 2011;171(5):438-43. PMID: 21403040. Available from: 10.1001/archinternmed.2011.13.

24. Zimmer JG, Bentley DW, Valenti WM, Watson NM. Systemic antibiotic use in nursing homes. A quality assessment. J Am Geriatr Soc. 1986;34(10):703-10. PMID: 3760435. Available from: 10.1111/j.1532-5415.1986.tb04301.x.

25. Pickering TD, Gurwitz JH, Zaleznik D, Noonan JP, Avorn J. The appropriateness of oral fluoroquinolone-prescribing in the long-term care setting. J Am Geriatr Soc. 1994;42(1):2832. PMID: 8277111 . Available from: 10.1111/j.1532-5415.1994. tb06069.x.

26. Loeb M, Simor AE, Landry L, Walter S, McArthur M, Duffy J, et al. Antibiotic use in Ontario facilities that provide chronic care. J Gen Intern Med. 2001;16(6):376-83. PMID: 11422634. Available from: 10.1046/j.1525-1497.2001.016006376.x.

27. Vergidis P, Hamer DH, Meydani SN, Dallal GE, Barlam TF. Patterns of antimicrobial use for respiratory tract infections in older residents of long-term care facilities. J Am Geriatr Soc. 2011;59(6):1093-8. PMID: 21539527. Available from: 10.1111/ j.1532-5415.2011.03406.x.

28. Prasad S, Smith P. Meeting the threat of Antibiotic Resistance: building a new frontline defence. Office of the Chief Scientist; 2013.

29. Luyt CE, Bréchot N, Trouillet JL, Chastre J. Antibiotic stewardship in the intensive care unit. Crit Care. 2014;18(5):480. PMID: 
25405992. Available from: 10.1186/s13054-014-0480-6.

30. Velden AVD, Duerden MG, Bell J, Oxford JS, Altiner A, Kozlov $\mathrm{R}$, et al. Prescriber and patient responsibilities in treatment of acute respiratory tract infections essential for conservation of antibiotics. Antibiotics (Basel). 2013;2(2):316-27. Available from: 10.3390/antibiotics2020316.

31. Walker S, McGeer A, Simor AE, Armstrong-Evans M, Loeb $M$ Why are antibiotics prescribed for asymptomatic bacteriuria in institutionalized elderly people? A qualitative study of physicians' and nurses' perceptions. CMAJ. 2000;163(3):2737. PMID: 10951723.

32. Schweizer AK, Hughes CM, Macauley DC, O'Neill C. Managing urinary tract infections in nursing homes: a qualitative assessment. Pharm World Sci. 2005;27(3):159-65. PMID: 16096881. Available from: 10.1007/s11096-005-1191-5.

33. Lim CJ, Kwong M, Stuart RL, Buising KL, Friedman ND, Bennett $\mathrm{N}$, et al. Antimicrobial stewardship in residential aged care facilities: need and readiness assessment. BMC Infect Dis. 2014;14(1):410. PMID: 25055957. Available from: 10.1186/ 1471-2334-14-410.

34. Kistler CE, Sloane PD, Platts-Mills TF, Beeber AS, Khandelwal C, Weber DJ, et al. Challenges of antibiotic prescribing for assisted living residents: perspectives of providers, staff, residents, and family members. J Am Geriatr Soc. 2013;61(4):56570. PMID: 23452167. Available from: 10.1111/jgs.12159.

35. Dartnell JG. Understanding, influencing and evaluating drug use: Therapeutic Guidelines. and others, editor; 2001

36. Duguid $M$, Cruickshank $M$. Antimicrobial stewardship in Australian hospitals 2011. Available from: https://www.safety andquality.gov.au/wp-content/uploads/2011/01/Antimicrob ial-stewardship-in-Australian-Hospitals-2011.pdf.

37. Rawlins M, McKenzie D, Mar CD. Antimicrobial stewardship: what's it all about? Aust Prescr. 2013;36(4).

38. Smith PW, Bennett G, Bradley S, Drinka P, Lautenbach E, Marx J, et al. SHEA/APIC Guideline: infection prevention and control in the long-term care facility. Am J Infect Control. 2008;36(7):504-35. PMID: 18786461. Available from: 10.1016/ j.ajic.2008.06.001.

39. Dyar OJ, Pagani L, Pulcini C. Strategies and challenges of antimicrobial stewardship in long-term care facilities. Clin Microbiol Infect. 2015;21(1):10-9. PMID: 25636921. Available from: 10.1016/j.cmi.2014.09.005.

40. Liberati A, Altman DG, Tetzlaff J, Mulrow C, G $\varnothing$ tzsche PC, loannidis JP, et al. The PRISMA statement for reporting systematic reviews and meta-analyses of studies that evaluate health care interventions: explanation and elaboration. J Clin Epidemiol. 2009;62(10):e1-34. PMID: 19631507. Available from: 10.1016/j.jclinepi.2009.06.006.

41. Mody L, Krein SL, Saint S, Min LC, Montoya A, Lansing B, et al. A targeted infection prevention intervention in nursing home residents with indwelling devices: a randomized clinical trial. JAMA Intern Med. 2015;175(5):714-23. PMID 25775048. Available from: 10.1001/jamainternmed.2015.132.

42. Zimmerman S, Sloane PD, Bertrand R, Olsho LE, Beeber A, Kistler $C$, et al. Successfully reducing antibiotic prescribing in nursing homes. J Am Geriatr Soc. 2014;62(5):907-12. PMID: 24697789. Available from: 10.1111 /jgs. 12784

43. Pettersson E, Vernby A, Mölstad S, Lundborg CS. Can a multifaceted educational intervention targeting both nurses and physicians change the prescribing of antibiotics to nursing home residents? A cluster randomized controlled trial. J Antimicrob Chemother. 2011;66(11):2659-66. PMID: 21893568. Available from: 10.1093/jac/dkr312.

44. Baldwin NS, Gilpin DF, Tunney MM, Kearney MP, Crymble L, Cardwell C, et al. Cluster randomised controlled trial of an infection control education and training intervention programme focusing on meticillin-resistant Staphylococcus aureus in nursing homes for older people. J Hosp Infect. 2010;76(1):36-41. PMID: 20451294. Available from: 10.1016/j. jhin.2010.03.006.

45. Monette J, Miller MA, Monette M, Laurier C, Boivin JF, Sourial $\mathrm{N}$, et al. Effect of an educational intervention on optimizing antibiotic prescribing in long-term care facilities. J Am Geriatr Soc. 2007;55(8):1231-5. PMID: 17661962. Available from: 10 . 1111/j.1532-5415.2007.01250.x.

46. van Gaal BG, Schoonhoven L, Vloet LC, Mintjes JA, Borm GF, Koopmans RT, et al. The effect of the SAFE or SORRY? programme on patient safety knowledge of nurses in hospitals and nursing homes: a cluster randomised trial. Int J Nurs Stud. 2010;47(9):1117-25. PMID: 20202633. Available from: 10.1016/j.ijnurstu.2010.02.001.

47. Zabarsky TF, Sethi AK, Donskey CJ. Sustained reduction in inappropriate treatment of asymptomatic bacteriuria in a longterm care facility through an educational intervention. Am J Infect Control. 2008;36(7):476-80. PMID: 18786450. Available from: 10.1016/j.ajic.2007.11.007.

48. Hasson H, Arnetz JE. The impact of an educational intervention for elderly care nurses on care recipients' and family relatives' ratings of quality of care: a prospective, controlled intervention study. Int J Nurs Stud. 2008;45(2):166-79. PMID: 17069817. Available from: 10.1016/j.ijnurstu.2006.09.001.

49. van Buul LW, van der Steen JT, Achterberg WP, Schellevis FG, Essink RT, de Greeff SC, et al. Effect of tailored antibiotic stewardship programmes on the appropriateness of antibiotic prescribing in nursing homes. J Antimicrob Chemother. 2015;70(7):2153-62. PMID: 25745104. Available from: 10 . 1093/jac/dkv051.

50. Jump RL, Olds DM, Seifi N, Kypriotakis G, Jury LA, Peron EP, et al. Effective antimicrobial stewardship in a long-term care facility through an infectious disease consultation service: keeping a LID on antibiotic use. Infect Control Hosp Epidemiol. 2012;33(12):1185-92. PMID: 23143354. Available from: $10.1086 / 668429$.

51. Daly PB, Smith PW, Rusnak PG, Jones MB, Giuliano D. Impact on knowledge and practice of a multiregional long-term care facility infection control training program. Am J Infect Control. 1992;20(5):225-33. PMID: 1443754. Available from: 10.1016/ S0196-6553(05)80195-6.

52. Linnebur SA, Fish DN, Ruscin JM, Radcliff TA, Oman KS, Fink $\mathrm{R}$, et al. Impact of a Multidisciplinary Intervention on Antibiotic Use for Nursing Home-Acquired Pneumonia. Am J Geriatr Pharmacother. 2011;9(6):44-50. Available from: 10.1016/j. amjopharm.2011.09.009.

53. Rummukainen $M L$, Jakobsson $A$, Matsinen $M$, Järvenpää $S$, Nissinen A, Karppi P, et al. Reduction in inappropriate prevention of urinary tract infections in long-term care facilities. Am J Infect Control. 2012;40(8):711-4. PMID: 22297240. Available from: 10.1016/j.ajic.2011.09.013.

54. Schwartz DN, Abiad H, DeMarais PL, Armeanu E, Trick WE, Wang $Y$, et al. An educational intervention to improve antimicrobial use in a hospital-based long-term care facility. J Am Geriatr Soc. 2007;55(8):1236-42. PMID: 17661963. Available from: 10.1111/j.1532-5415.2007.01251.x.

55. Naughton BJ, Mylotte JM, Ramadan F, Karuza J, Priore RL. Antibiotic use, hospital admissions, and mortality before and after implementing guidelines for nursing home-acquired pneumonia. J Am Geriatr Soc. 2001;49(8):1020-4. PMID: 11555061. Available from: 10.1046/j.1532-5415.2001.49203.x.

56. Fleet E, Rao GG, Patel B, Cookson B, Charlett A, Bowman C, et al. Impact of implementation of a novel antimicrobial stewardship tool on antibiotic use in nursing homes: a prospective cluster randomized control pilot study. J Antimicrob Chemother. 2014;69(8):2265-73. PMID: 24777901. Available from: 10.1093/jac/dku115.

57. Loeb M, Brazil K, Lohfeld L, McGeer A, Simor A, Stevenson K, et al. Effect of a multifaceted intervention on number of antimicrobial prescriptions for suspected urinary tract infections in residents of nursing homes: cluster randomised controlled trial. bmj. 2005;331(7518):669.

58. Thomas B, Ciliska D, Dobbins M, Micucci S. Quality Assessment Tool for Quantitative Studies Dictionary: The Effective Public Health Practice Project (EPHPP). McMaster University; 2008. 
59. Schwartz DN, Abiad H, DeMarais PL, Armeanu E, Trick WE, Wang $Y$, et al. An Educational Intervention to Improve Antimicrobial Use in a Hospital-Based Long-Term Care Facility: (See Editorial Comments by Dr. Lona Mody on pp 1301-1302). J Am Geriatr Soc. 2007;55(8):1236-42. PMID: 17661963. Available from: 10.1111/j.1532-5415.2007.01251.x.

60. Ranji SR, Steinman MA, Shojania KG, Sundaram V, Lewis R, Arnold S. Closing the quality gap: a critical analysis of quality improvement strategies. vol. 4: antibiotic prescribing behavior. Technical Reviews, No. 9.4; 2006.

61. Giguère $A$, Légaré $F$, Grimshaw J, Turcotte $S$, Fiander $M$, Grudniewicz $A$, et al. Printed educational materials: effects on professional practice and healthcare outcomes. Cochrane Database of Systematic Reviews. 2012;2010(10). Available from: 10.1002/14651858.CD004398.pub3.

62. Ivers N, Jamtvedt G, Flottorp S, Young JM, Odgaard-Jensen J, French SD, et al. Audit and feedback: effects on professional practice and healthcare outcomes. Cochrane Database Syst Rev. 2012;6(6):000259. PMID: 22696318. Available from: 10 1002/14651858.CD000259.pub3.

63. Arnold SR, Straus SE. Interventions to improve antibiotic prescribing practices in ambulatory care. Cochrane database of systematic reviews. 2005;2005(4). Available from: 10.1002/ 14651858.CD003539.pub2.
64. Samore MH, Bateman K, Alder SC, Hannah E, Donnelly S, Stoddard GJ, et al. Clinical decision support and appropriateness of antimicrobial prescribing: a randomized trial. JAMA. 2005;294(18):2305-14. PMID: 16278358. Available from: 10. 1001/jama.294.18.2305

65. Sintchenko V, Iredell JR, Gilbert GL, Coiera E. Handheld computer-based decision support reduces patient length of stay and antibiotic prescribing in critical care. J Am Med Inform Assoc. 2005;12(4):398-402. PMID: 15802478. Available from: 10.1197/jamia.M1798.

66. Davey P, Brown E, Charani E, Fenelon L, Gould IM, Holmes A et al. Interventions to improve antibiotic prescribing practices for hospital inpatients. Cochrane Database Syst Rev. 2013;4(4):003543. PMID: 23633313. Available from: 10.1002/ 14651858.CD003543.pub3.

67. Tamma P. Antimicrobial Stewardship, An Issue of Infectious Disease Clinics. Elsevier Health Sciences; 2014.

68. Yong MK, Buising KL, Cheng AC, Thursky KA. Improved susceptibility of Gram-negative bacteria in an intensive care unit following implementation of a computerized antibiotic decision support system. J Antimicrob Chemother 2010;65(5):1062-9. PMID: 20215130. Available from: 10.1093/ $\mathrm{jac} / \mathrm{dkq} 058$. 